\title{
МЕТОДИ ВИВЧЕННЯ РУХОВОЇ АКТИВНОСТІ У ТВАРИН
}

\author{
В. Данчук
}

Національний університет біоресурсів і природокористування Украйни

\author{
Т. Приступа, М. Клюцук \\ Подільський державний аграрний університет \\ О. Данчук \\ Одеський державний аграрний університет
}

У огляді літератури наведені відомі методи вивчення рухової активності у тварин. Рухова активність тварин - ие координоване скорочення скелетних м'язів, яке супроводжується зміною положення тіла в просторі. Рухова активність організму здійснюється за допомогою системи руху. ЦНС відповідає з координацію рухів тіла, а самі рухи виконуються м'язами за допомогою кісток скелета та їх з'єднань (суглобів, а також нерухомих та малорухомих з'єднань кісток). Усі кістки об'єднуються між собою різними видами сполучної тканини і утворюють скелет - пасивну частину системи руху, а прикріплені до кісток скелетні м'язи - ї̈ активну частину. $C$ досить багато методів і підходів визначення рухової активності тварин. Метою даної роботи було науково обтрунтувати та узагальнити існуючі методи визначення рухової активності сільськогосподарських та домашніх тварин і птиці.

Ключові слова: рухова активність, етологія, тварини.

Рух - це моторна функція організму, що виражається у зміні положення тіла або окремих його частин. Розрізняють вроджені і довільні рухи. Рух тварини здійснюють за допомогою рухового апарату. Якщо в загальному розглянути усі рухи тварин, їх можна розділити на: стрибки, політ, повзання, ходіння, біг та плавання [1]. Ці основні рухи плавно переходять одні в інші інколи через різні статичні пози (лежання, стояння, сидіння). Завдання рухової активності - забезпечення взаємодії тварини 3 довкіллям. Опанування скоординованим скороченням певних груп м'язів для виконання складних рухів потребує тривалих тренувань і може наступати через досить значний період після народження [2].

Фізіологічні характеристики цілеспрямованого руху тварин визначає не тільки інтенсивність скорочення м'яза та положення тіла на тому чи іншому етапі. Під час руху центральна нервова система постійно шляхом сенсорних корекцій корегує рух, внесених в моторні імпульси на основі сенсорної інформації про хід виконання руху [3]. Це призводить поступово до автоматизації руху. У міру повторення руху, в тварини відбувалося формування м'язового почуття правильного руху. Поступово відбувається повна передача окремих компонентів руху або всього руху цілком у керівництво автоматичними рухами (ходіння, повзання, біг, політ, плавання).

Рухові дії протягом онтогенезу мають тенденцію до ускладнення. Поступово проходить дозрівання вроджених механізмів, що беруть участь у 
координації рухів. Поряд з тим з'являється механізм навчання - формування нових зв'язків, що лягають в основу програм тих чи інших конкретних рухових актів. Із початку навчання центральна нервова система справляється 3 труднощами, зумовленими великою кількістю ступенів свободи в опорноруховому апараті і впливом на результат руху сил ваги й інерції, за допомогою додаткового м'язового напруження [2]. М'язовий апарат жорстко фіксує суглоби, що не беруть участь у русі, і активно гальмує інерцію швидких рухів. Такий спосіб подолання перешкод вимагає зайвих енерговитрат [4]. Використання зворотних зв'язків ще недосконале. Тому складна рухова активність на перших етапах навчання нераціональна, досить напружена. У ході навчання поступово виробляється така структура рухового акту, за якої в його динаміку включаються нем'язові сили, які стають складовою частиною рухової програми [5]. М'язове напруження при цьому усувається, рух стає більш стійким до зовнішніх впливів. М'язова діяльність стає більш економічною, точною і ефективною.

Обсяг рухової активності протягом доби у сільськогосподарських тварин переважно є постійною величиною. Вона має виражені видові й індивідуальні особливості. Інтенсивність рухової активності на певних етапах онтогенезу зумовлюється генетично, але може моделюватися чинниками середовища, у тому числі і етологічного походження [5]. Рухова активність вимірюється одиницями витраченої енергії за певний час або кількістю здійснених рухових дій за певний час. Кількість енергії, яку витрачає організм в звиклих умовах на рухову активність є стабільною.

Хімічна енергія, яка утворюється в організмі, має чітку спеціалізацію іiі використання [4]. Якщо проходить переорієнтація на окремі напрямки, то може розвиватись патологія, проте інколи це є бажаний для виробництва продукції тваринництва ефект. Так, зниження рухової активності призводить до надмірного депонування хімічної енергії, ожиріння, ослаблення рухового апарату. Або, інтенсивна рухова активність призводить до схуднення, зниження середньодобових приростів [5]. Слід зауважити, що даний погляд на розподіл енергії стосується тільки тих випадків, коли тварини знаходяться на одному i тому ж раціоні. Зміна інтенсивності надходження поживних речовин протягом доби істотно впливає на прояви рухової активності.

Цікавим є порівняння рухової активності (сон, лежання на правому та лівому боці, сидіння, стояння, прийняття корму, комфортні рухи) у диких та домашніх свиней. Н. Кисляков встановив, що кабан з’їдає свій раціон, практично не відриваючись від корму, а кнур перериває їжу комфортним рухом, що підвищує індекс його харчової активності [6]. Дослідники дійшли висновку, що дикий кабан і домашні свині на сон використовують приблизно однакову кількість часу дня, а бездіяльне лежання в домашніх свиноматок учетверо довше.

Рух тварин, як фізіологічне явище має свої характеристики: положення тіла та траєкторія (шлях) руху. Яку б рухову дію не виконувала тварина, вона повинна надати своєму тілу певного положення у просторі. Збереження нерухомого положення тіла та окремих його частин здійснюється завдяки 
статичному напруженню м'язів. Розрізняють вихідні, проміжні та кінцеві положення тіла. Вихідні положення приймають для створення найбільш вигідних умов для початку руху, кращого орієнтування у навколишніх обставинах, збереження стійкості, забезпечення свободи рухів, відповідної дії на певні органи і системи організму [1]. Проміжні положення. Ефективність багатьох рухових дій залежить не тільки від вихідного положення, що передує початку рухів, а й від збереження найбільш вигідної пози тіла або будь-яких його частин у процесі виконання самого руху. Кінцеві положення в окремих видах рухової діяльності також відіграють важливу роль, наприклад приземлення після зіскоку.

Траєкторія руху - це шлях, що проходить та або інша частина (точка) тіла у просторі. Траєкторія руху характеризується формою, напрямком та амплітудою. Форма траєкторії може бути прямолінійною та криволінійною. Прямолінійні рухи у практиці зустрічаються надто рідко [3]. Пояснюється це тим, що рухи в окремих суглобах (кінцівки) мають обертальний характер, тому криволінійні траєкторії рухів найбільш природні для тварини. Напрямок руху це зміна положення тіла та його частин у просторі відносно до будь-якої поверхні (фронтальної, сагітальної, горизонтальної) або будь якого зовнішнього орієнтиру. Розрізняють напрямки: основні (вгору-вниз, уперед-назад, праворучліворуч) і проміжні (уперед-вгору, уперед-донизу та ін.). Амплімуда руху - це величина шляху переміщення окремих частин тіла відносно одна одної або осі зовнішнього орієнтиру. Амплітуда рухів вимірюється у кутових градусах або у лінійних мірах. Часто їі визначають відносно положення інших частин тіла або відносно будь-яких зовнішніх.

Часові характеристики руху характеризуються тривалістю і темпом руху. Тривалість руху - це час, який витрачено на його виконання. У техніці руху тварин велике значення має тривалість окремих його частин, фаз, циклів, елементів рухів або рухів окремих частин тіла. Від тривалості залежать практичні досягнення в багатьох рухових діях [2]. Тривалість кожної фази, періоду, циклу у русі можна виміряти i визначити іiі дію на результат (наприклад, тривалість періодів опори і польоту у бігу). Зміна часу виконання рухової дії може впливати на діяльність відповідних органів і систем організму. Tемn pyxy - це частота відносно рівномірного повторення будь-яких рухів. Темп рухів знаходиться в обернено пропорційній залежності від рухової діяльності: чим вона менша, тим він вищий, наприклад, зменшення тривалості кроку у бігу на певній дистанції веде до підвищення частоти кроків. Максимальна частота рухів є одним з показників швидкості як фізичної якості тварини [5]. Не слід ототожнювати поняття темпу і швидкості рухів, хоча часто (але не завжди) швидкість рухів залежить від темпу і навпаки. Так, у бігу зі збільшенням темпу (при одній і тій самій довжині кроку тварини) неминуче збільшується швидкість рухів у кожному кроці, але якщо одночасно зі збільшенням темпу зменшується довжина кроків, то швидкість рухів може залишитися і незмінною.

Рухова активність тварин - фізіологічний процес, що залежить від психічної активності тварин і проявляється у вигляді поведінки. Поведінка - це 
система взаємопов'язаних реакцій, що здійснюються живими організмами для пристосування до середовища, виконання нагальних потреб і відтворення виду.

Поведінка сільськогосподарських та домашніх тварин може бути: пошуково-кормова та мисливська; територіальна (обхід своєї території, або перехід на іншу територію, маркування кордонів території і т.д.); оборонного muny (пасивне i активне уникнення небезпеки, уникнення зустрічі, втеча, переадресована агресія і т.д.); орієнтаційна та пошуково-дослідницька (спостереження за довкіллям, маркування орієнтирів); комфортна (перехід до відпочинку, чистка, вибір та підготовка місця сну, лежання); комунікаційна (прояви страху, гніву, задоволення, голоду, болю та інертність до подій, що відбуваються; використовуються різні типи сигналів: хімічні, тактильні, звукові i зорові); ігрова (включає усі аспекти життя тварин даного виду - ієрархічні відношення в групі; репродуктивну поведінку, елементи розбудови гнізда, піклування про потомство, пошуку корму, захисних реакцій або нападу і т.д.); репродуктивна поведінка тварин (пошук пари, ритуальні танці, бої, вибір пари, догляд за своєю парою, догляд та навчання молодняку) [7].

Геніальний учень І.П. Павлова - Петро Кузьмич Анохін - запропонував іще в першій половині минулого століття теорію функціональної системи, яка комплексно розкриває механізми поведінкових реакцій. Функціональні системи (за П.К. Анохіним) - це динамічні організації, що саморегулюються, діяльність усіх складових компонентів яких сприяє отриманню життєво важливих для організму пристосувальних результатів [5, 9]. Виділяються два типи функціональних систем: системи першого типу забезпечують гомеостаз за рахунок внутрішніх (вже наявних) ресурсів організму, не виходячи за його межі (рН крові, буферні системи, артеріальний тиск, і інші показники); системи другого muny підтримують гомеостаз за рахунок зміни поведінки, взаємодії із зовнішнім світом і лежать в основі різних типів поведінки, які задовольняють потреби однієї особини або групи тварин. Згідно теорії функціональних систем поведінкові акти у тварин перебігають у декілька стадій [10]:

1. Аферентний синтез - стадія функціонування системи, що ініціюється певною потребою, для задоволення якої і включається в роботу функціональна система. Проробляється причинно-наслідковий ланцюг фізіологічних процесів. До компонентів аферентного синтезу входять домінуюча на даний момент мотивація (спонукання до дії), установча аферентація, яка також відповідає даному моменту, пускова аферентація (збудження, викликані умовними i безумовними подразниками) і пам'ять (видова та індивідуальна).

2. Прийняття рішення - ця стадія характеризується вибором основної для даного моменту "лінії поведінки" (в окремих аспектах залежить від типу ВНД у тварин).

3. Формування акцептора результату дії (створення ідеального образу результату і його утримання).

4. Еферентний синтез (або ж стадія програми діï) - стадія, на якій відбувається динамічне об'єднання соматичних i вегетативних функцій в єдиний поведінковий акт, який іще не проявляється ззовні. 
5. Цілеспрямована дія - (виконання програми поведінки).

6. Санкціонуюча стадія (оцінка результату дії) - порівняння реально виконуваної дії з ідеальним образом, створеним на етапі формування акцептора результату дії (відбувається зворотна аферентація); на підставі результатів порівняння дія або коригується, або припиняється.

7. Задоволення потреби (стадія санкціонуються припинення діяльності).

Слід зауважити, що на сьогоднішній день ніхто іще не виявив ніяких анатомічних утворень, які в комплексі відповідають за ту чи іншу поведінку тварин. Проте створена модель значно спрощує вивчення рухової активності тварин залежно від різних факторів [11].

Безумовно, тип ВНД та статус тварини в їх соціумі істотно впливає на їі поведінку. Проте, інколи дослідників цікавить як той чи інший фактор впливає на загальну рухову активність тварин незалежно від іiі статусу в групі або типу ВНД. Точніше кажучи, скільки з одержаної енергії раціону витрачається на рухову активність [10]. Такого роду дослідження пов'язані в основному 3 удосконаленням умов утримання, складу раціону та різних технологічних прийомів у виробництві продукції тваринництва. Наприклад, зниження рухової активності свині на відгодівлі $€$ безумовно позитивним фактором для виробництва [12]. Хімічна енергія не витрачається на забезпечення скорочення м'язів, а використовується на синтез органічних молекул [4]. Тварина має більші середньодобові прирости. У той же час ремонтний молодняк обов'язково повинен мати певний рівень моціону. Саме за таких умов тіло тварини та статеві органи розвиваються збалансовано і можна отримати гарну свиноматку.

Вивчення рухової активності. Існує декілька підходів аналізу рухової активності сільськогосподарських тварин. Перший - клінічний (передбачає виключення різних патологій рухової активності заразної та незаразної етіологіï) $[13,14]$. Наприклад, доводиться часто чути: тварина щось лежить, не їсть, накульгує і т.д. Другий - етологічний (розглядає рухову активність за складовими поведінки тварин. Метод передбачає спостереження за повсякденною життєдіяльністю тварин в умовах природного експерименту або у штучно створених експериментатором ситуаціях). Третій - фізіологічний (розглядає сумарну рухову активність за певні проміжки часу залежно від інтенсивності обміну речовин та характеристик навколишнього середовища).

Клінічні методи визначення рухової активності. Ветеринарні методи дослідження рухової активності скелетних м'язів спрямовані перш за все на визначення фізіологічного стану тварини, тому істотно відрізняються від інших. Вони передбачають попереднє опитування господаря тварини та огляд тварини. При потребі використовують специфічні клінічні методи досліджень. Анамнез - отримання інформації про тварину шляхом розпитування. Мета огляду тварин - встановити фізіологічний стан тварини за видимими ознаками i дати висновок про іiї придатність до промислового використання: одержання потомства, продукції тваринництва (молоко, яйця, вовна і т.д.) та забою на м'ясо. У разі відхилень у поведінці звертають увагу на функцію нервової системи (пригнічення, збудження, тремтіння, переступання ногами, зміну пози, 
вирячкуватість, полохливість тощо). Поведінку тварин досліджують переважно шляхом спостереження за ними та вивченням їх реакцій на безумовні й умовні подразники. Порушення поведінки тварин та рухів тварин класифікують наступним чином: пригнічення (апатія, сонливість, сплячка, коматозний стан); збудження; вимушені рухи та положення тіла. Особливу увагу та обережність слід проявляти в тих випадках, коли у тварин спостерігається раніше не властива їм виражена агресивність [10]. Порушення діяльності кори великих півкуль викликає відповідні розлади поведінки тварин.

Етологічні методи досліджень. Основне завдання етології - дати філогенетичне та фізіологічне пояснення функціональних взаємозв'язків між факторами, що формують поведінку живих істот та впливають на неї. У класичній етології застосовувалося одночасно два основних методи описання видоспецифічної поведінки: за допомогою зображень (малюнків, фотографій) i словесне описання [1]. Повне описання видоспецифічної поведінки тварин (3 використанням об'єктивних методів реєстрації - відеозйомки, магнітофонних записів, хронометражу) називається етограмою. Етограми можуть бути представлені у вигляді таблиці ознак, що збігаються і не збігаються у різних тварин. У таблиці, як правило представляють види рухової активності, що характеризують поведінку тварин даного виду в окремі періоди біологічного та технологічного циклу. Фактори, які впливають на рухову активність клінічно здорових тварин в умовах виробництва, є дуже різні (зміни умов утримання та годівлі, спарювання, вирощування молодняку, стадні відносини та ін.).

Метод мічення тварин. Мічення тварин або мічення 3 «поверненням» (повторна реєстрація поміченої особи) поставляє необхідні матеріали при вивченні питань міграції, дослідженні територіальних зв’язків, визначенні чисельності популяції й середньої та максимальної тривалості життя тварин у природі, ступеня контактів та взаємовідносин між співтовариствами, стадами, зграями, сім'ями та окремими особинами. Розрізняють індивідуальне та групове мічення.

Метод аналізу бюджету часу та енергії. Бюджет часу - це перелік форм поведінкових реакцій тварин і розподіл їх в часі. Бюджет енергії - перелік того, на що і скільки енергії використано - по суті, також характеризує поведінку, але $з$ іншої точки зору. Бюджет часу тварин установлюється хронометруванням їх поведінки, статистичними дослідженнями динаміки груп тварин (зграй птахів), радіостеженням [10]. Бюджет часу тварини є інформативним сам по собі, але можливості його розуміння обмежені, оскільки бракує бюджету енергії. Інформативність бюджету часу зростає, коли на його основі розрахувати бюджет енергії тварин. Для цього час, витрачений на кожну 3 активностей, необхідно помножити на їі енергетичну ціну, яка встановлюється в лабораторних умовах.

Метод моделювання - це дослідження процесів або станів, форм поведінки за допомогою їх реальних (фізичних) або ідеальних, насамперед математичних, моделей [5]. При цьому під словом «модель» розуміють систему об'єктів або знаків, що відтворює деякі суттєві властивості системи-оригіналу. Наявність часткової схожості дозволяє використовувати модель як замісника або 
представника даної системи. Створення спрощених моделей системи - дієвий засіб перевірки істинності та повноти теоретичних уявлень.

Метод часових зрізів рекомендований для реєстрації всіх або більшості форм поведінки в умовах обмеження часу спостереження (погодні умови, стомлюваність дослідника, стрес піддослідної тварини). Збір матеріалу проводиться протягом короткочасних періодів, через рівні проміжки часу. Перевагою методу є його чіткий збір даних за періодами, що полегшує обробку, інтерпретацію результатів i служить хорошою базою для достовірного статистичного аналізу [10]. Тривалість проміжків між фіксаціями вибирається залежно від об'єктів. Слід чітко дотримуватись термінів спостерігання та відпочинку, захоплювати повністю одну фазу виробничого циклу (або весь цикл) і фіксувати активність тварин у певний період дня (до годівлі, підчас годівлі, після годівлі і т.д.). Тривалість проміжків між фіксаціями залежить від поведінки дослідних тварин; числа тварин, що перебувають одночасно під контролем, і завдань дослідника. Базовий інтервал реєстрації - 10 секунд реєстраціі/10 секунд відпочинку.

Метод реєстрації окремих поведінкових проявів. Цей метод застосовують, коли дослідника цікавлять лише окремі поведінкові реакції (прийом корму, лактація, статева активність, агресивна поведінка і т.д.). Під час спостереження фіксують лише випадки потрібної рухової активності або поведінки тварин. Результати, отримані даним методом, не дають можливості судити про загальний розподіл часу за різними видами рухової активності, але дозволяють визначити частоту, тривалість, послідовність і спрямованість поведінкових реакцій, які цікавлять дослідника [10]. Процедура спостереження даним методом полягає в тому, що дослідник постійно тримає в полі зору тварин i відзначає всі випадки прояву досліджуваної пози, акту поведінки або ансамблю. Якщо враховується тривалість проявів, то час засікається за допомогою годинника з секундоміром або використовують аудіозапис відліку часу. Найбільш типові завдання, які вирішуються цим методом - вивчення тривалості тих чи інших фізіологічних процесів в групі тварин (годівля, лактація, агресивні взаємодії, відпочинок і сон).

Метод стимул-реакиія. Метод передбачає визначення того, як реагує тварина на визначені дослідником чинники (компоненти корму, моціон, плідник, потомство, технічний працівник і т.д.) [2]. Специфіка методу стимулреакція в тому, що при наявності стимулу реєструють не тільки очевидні зміни в стані тварини (реакції), але й факт відсутності таких реакцій. Можливо й зворотне - визначення того, яка частка очевидних змін у поведінці не пов'язана 3 існуючими зовнішніми стимуляторами в даний час. Оптимальна форма ведення записів - таблиця, в першій графі якої - час у другій - дані про потенційні стимулятори, в третій - опис реакції тварини або відмітка про те, що видимої реакції немає. При спостереженні за декількома тваринами одночасно необхідно враховувати, що зміни в поведінці одного 3 них (реакція) $\epsilon$ потенційним стимулом для інших. 
Метод суиільного протоколювання. Метод базується на безперервному i максимально повному записі усіх дій тварини (спостерігати цим методом більш ніж за однією твариною одночасно неможливо). Метод дозволяє виділяти поведінкові послідовності різних рівнів, оцінювати загальні часові характеристики рухової активності та поведінки тварин, встановлювати функціональні залежності між різними поведінковими проявами. Це надзвичайно трудомісткий метод i потребує багато людських ресурсів (погодинні чергування дослідників протягом декількох діб) [3]. Неможливо спостерігати за кількома тваринами відразу. Отримується величезна кількістю додаткової інформації, що не входить у плани дослідника.

Фізіологічні методи досліджень. Використовуючи фізіологічні методи дослідження рухової активності, дослідник вирішує декілька завдань: вивчає біоелектричні процеси у м'язах при роботі, встановлює тип вищої нервової діяльності у тварини, досліджує силу, ритмічність та інтенсивність скорочення м'язів, оцінює моторну функцію та координацію рухів, витрату енергії для рухової активності і т.д.

Електрофізіологічні методи досліджень: клітинна електрофізіологія (дослідження струмів і потенціаллів окремих клітин чи навіть ділянок мембрани); електрокардіографія (дослідження потенціалів серця); електроенцефалографія (дослідження потенціалів мозку); електроміографія (дослідження потенціалів м'язів); електроретинографія (дослідження потенціалів сітківки); електрогастрографія (дослідження електричної активності шлунка і кишок) [10].

Електроміографія - це метод вивчення біоелектричних процесів, що розвиваються в м'язах тварин під час їх скорочення. Метод заснований на запису біопотенціалів скелетних м'язів. Дослідження проводиться за допомогою спеціальних приладів - електроміографів. Амплітуда коливань потенціалу м'яза зазвичай не перевищує кількох мілівольт, а їх тривалість - 2025 мсек. тому електроміографію проводять за допомогою підсилювача i малоінерційного реєстратора. Крива, записана на фотопапері, фотоплівці і т. п., називається електроміограмою. Таким чином досліджується нервово-м'язова передача, рефлекторна діяльність рухового апарату, визначається швидкість проведення збудження по нерву [2]. Це дає можливість судити про стан i діяльність не тільки м'язів, але й нервових центрів, що беруть участь у здійсненні рухів. Ї̈̈ застосовують у фізіології при вивченні рухової функції тварин.

Метод стабілографіiї. Стабілографія - це метод кількісного, просторового та часового аналізу стійкості вертикальної пози тварини. Суть методу зводиться до оцінки біомеханічних показників тварини в процесі підтримки нею вертикального положення тіла. Утримання рівноваги твариною $є$ результатом взаємодії вестибулярного i зорового аналізаторів, рухового апарату, центральної та периферичної нервової системи. Тому координація вертикального положення тіла служить своєрідним індикатором стану функціонального розвитку тварини на різних етапах онтогенезу або під час модельних дослідів. 
Метод вимірювання сили хватки щурів і мишей. Вимірювач сили хватки призначений для вивчення нервово-м'язових функцій у гризунів [10]. Тварину тримають за хвіст і дозволяють вхопитися за металеву решітку або трикутну рамку приладу, який потім реєструє максимальну силу хватки, розвинену твариною. Зміна сили хватки інтерпретується залежно від завдань дослідника.

Метод використання рота-роду для щурів та мишей. Зазвичай тварина поміщається на обертову вісь в свій відсік установки RotaRod, після чого запускається таймер [20]. У момент, коли тварина все ж таки падає, вона натискає своєю вагою на педальку внизу відсіку. При цьому реєструється час $\mathrm{i}$ поточна швидкість обертання осі. Знімний роздільник використовується для того, щоб уникнути перешкод, у разі якщо кілька тварин одночасно випробовуються на установці - кожне в своєму відсіку.

Метод бігової доріжки. Бігова доріжка використовується для вивчення впливу рухової активності тварини на функціонування різних органів і систем. $€$ різні види бігових доріжок. Одні передбачають фіксацію тварини за ошийник, наприклад, до виключення електричної доріжки підводимо собаку. На собаку одягаємо зручний для неї нашийник і прикріплюємо недовгий поводок, який тримаємо в руці (собаку до доріжки не прив'язувати). Заводимо тварину на виключену доріжку і даємо ласощі. Включаємо доріжку. Поводок тримаємо в руці, на іншому кінці поводка - собака [3]. Включаємо мінімальну швидкість і поступово збільшуємо іiі до потрібного рівня. Важливо не налякати собаку. Вона повинна спокійно і впевнено виконувати необхідну вправу. Інша група бігових доріжок використовуються для примусових вправ і точної оцінки розвитку втоми у гризунів. Бігова доріжка являє собою стрічку, що рухається 3 необхідною швидкістю і нахилом. Тварини спонукаються до бігу за допомогою електричного удару електрода, поміщеного в задньому кінці доріжки (струм може коливатись від 0 до 3,5 мА). Швидкість стрічки можна контролювати за допомогою комп'ютера. Прилад дозволяє оцінити загальну відстань пробігу, число отриманих електричних ударів і загальний час навантаження.

Метод використання ротамеру. Ротамер використовується для оцінки обертальної поведінки у гризунів. На досліджувану тварину надягають фіксатор, який регулюється, і яка під'єднується до датчика обертання за допомогою еластичної стрічки [10]. Тварина поміщається в прозорий контейнер, після чого ротаметр записує число часткових і повних обертів за годинниковою і проти годинникової стрілки під час дослідження твариною навколишнього середовища (параметр, який змінюється у тварин 3 різними порушеннями ЦНС, зокрема, хворобою Паркінсона).

Метод використання інфрачервоного актиметра. Інфрачервоний актиметр включає в себе двомірну квадратну раму і систему інфрачервоних променів для детектування рухів тварини [10]. Актиметр дозволяє досліджувати довільну рухову активність, кількість і тривалості епізодів вставання на задні лапи, стереотипних рухів, поведінки в умовах денного i нічного освітлення. Програмне забезпечення дозволяє зробити аналіз траєкторії руху тварини (відстані, швидкості, часу, проведеного в певних зонах). Це $є$ один із способів для оцінки опорно-рухової активності гризунів. 
Метод стаціонарних спостережень рухової активності. Найбільш загальним поширеним методом дослідження інстинкту як форми поведінки тварин $\epsilon$ спостереження. Опис поведінки тварини, зіставлення його особливостей у різних видів, встановлення характеру поведінки залежно від сезонів року, часу доби, наявності інших тварин і т. д. Для багатьох поколінь вчених стало основним прийомом вивчення інстинкту [6]. Ці методи не могли висвітлити таких питань, як походження інстинкту, фізіологічні механізми, які лежать в його здійсненні, роль успадкованих елементів і придбаних у типовому для даного виду поведінці і т. д. При вивченні природної рухової активності будь-якої тварини в його природному середовищі існування або в приміщенні, на фермі необхідно виключити вплив присутності самого дослідника на поведінку та рухову активність тварин. $Є$ два підходи вивчення рухової активності тварин за допомогою відеофіксації: відеореєстрація рухової активності тварин та безперервна відеореєстрація.

Метод використання відео реєстраторів рухової активності тварин. Цей фізіологічний метод реєструє виключно рухову активність тварин протягом доби (прийом води, корму, агресивні взаємодії, вимушені і не вимушені рухи і т.д.), проте статичні пози тварин він не реєструє, причому, запис звуків проводиться виключно при проявах рухової активності. Дослідник отримує відеозаписи і після їх аналізу можна легко визначити час рухової активності за наступними критеріями: споживання води і корму, рух тварини і відпочинок. Метод дає об'єктивну картину зміни рухової активності тварин залежно від періоду онтогенезу, технологічної групи, дії стресора, зміні компонентів корму і т.д. Дослідник може внести господарству свої рекомендації для відновлення фізіологічних параметрів рухової активності тварин. Наприклад: змінити свинарку, перевести тварину в іншу клітку, перегрупувати тварин, замінити корм і т.д. Цей метод крім відео реєстратора, потребує може використовувати й інше складне обладнання. Воно дає змогу за допомогою програм детально вивчити рухову активність та поведінку сільськогосподарських і домашніх тварин в стаціонарних умовах [10]. Метод дає можливість, крім написання ехограм, проводити кореляційні дослідження між фізіологічними реакціями (наприклад, частоти дихання серцевих скорочень, показники, артеріального тиску, температури тіла) і певною поведінкою. Спостерігач має кілька варіантів для інтеграції і синхронізації результатів від декількох систем збору даних. Дослідник може вибрати і проаналізувати їх у поєднанні з вашими поведінковими спостереженнями. Це дозволяє досліджувати те, що тварина зробила за певний проміжок часу у поєднанні з аналізом різних фізіологічних параметрів (частота серцевих скорочень, середня температура тіла, частота дихання і т.д.)

Метод визначення індексу рухової та кормової активності. Індекс рухової активності визначають на підставі подобових записів. $\mathcal{C}$ декілька підходів до визначення показника. Індекс рухової активності може враховувати деякі видові особливості тварин, наприклад час жуйки лежачи у жуйних тварин. Визначення індексу рухової активності (IPA) для моногастричних тварин проводять за формулою: IPA $=\Sigma \mathrm{tA}: \mathrm{t}$. Де $\Sigma \mathrm{tA}-$ час, коли тварина знаходилась 
у активному стані; $\mathrm{t}$ - загальний час спостереження. Визначення іиндексу рухової активності для жуйних тварин проводять за формулою формулі: IPA = час стояння + жуйка лежачи/ 720(1). Визначення індекс кормової активності (ITA) розраховують за формулою: IКА = час споживання корму + час жуйки/ 720 (2), де 720 - час спостереження у хвилинах за добу [10].

Ведення записів спостережень. Незалежно від мети досліджень і конкретних завдань дослідження необхідно дотримання правил ведення протоколу дослідження [10]. Кожен протокол повинен містити: дату дослідження; період спостережень (в годинах або хвилинах); місце спостереження (в яких умовах утримується тварина); коротку характеристику зоогігієнічних умов (температура в приміщенні, швидкість руху повітря, вологість, наявність і напрям вітру, хмарність i т. д. залежно від умов утримання тварини); загальний стан тварини до початку спостереження (клінічно здорова, рухлива, малоактивна, збуджені i т.д.); загальна характеристика тварини (вид, порода, стать, вік, маса, продуктивність, фізіологічний стан, кличка, номер); прізвище та підпис того, хто проводив спостереження.

Запропонований нами метод дослідження рухової активності свиней. Основним методом у вивченні поведінки тварин є безпосереднє спостереження [10]. Щоб мати об'єктивне уявлення про динаміку характерних поведінкових реакцій організму необхідні візуальні спостереження за тваринами протягом 2 3-ох суміжних діб. Вимірювання поведінкових реакцій здійснюють як в абсолютних величинах (час, витрачений протягом доби на певні прояви рухової активності та відпочинок), так і у відносних величинах (відсотках, тобто співвідношення різних форм рухової активності та відпочинку) [14]. Слід відзначити, що для комплексного вивчення поведінки свиней необхідно досліджувати не тільки прояви рухової активності, але і фізіологічний стан функціональних систем, що сприяють прояву активності тварин (стан нервової системи, активність залоз внутрішньої і зовнішньої секреції, морфологічні та біохімічні показники крові) [15]. Хронометраж поведінки тварини, зокрема, i вивчення рухової активності проводять шляхом вимірювання в часі дій тварини протягом дня або доби. Досліджуючи поведінку тварин звертають увагу на дії, що спрямовані на забезпечення життєдіяльності (прийом корму, сон, відпочинок, стояння, рухи) та дії, що спрямовані на зв'язок із навколишнім середовищем (голосові сигнали, агресивні взаємодії, не агресивні взаємодії і т.д.) [16]. Спостереження за тваринами протягом доби дозволяє встановити ритмічність поведінкових реакцій. Особливо важливі спостереження в періоди технологічних маніпуляцій (відлучення від свиноматки, перегрупування, заміна корму, підсаджування поросят до інших свиноматок та ін.) [10]. Такі дослідження дають повну картину щодо змін рухової активності на різних етапах технологічного процесу, що дає змогу розробити нові методи корекції поведінки тварин [17]. На даний час найбільш простим і поширеним методом реєстрації результатів спостережень є складання протоколів або етограми спостережень [10]. 
Найбільшої уваги 3 огляду на вище сказане заслуговує використання методики дослідження поведінки тварин запропонованої В.I. Велікжаніновим (1979) [10]. Методика включає систему скорочень для характеристики окремих актів поведінки. Реєструється витрачений час на здійснення поведінкових актів протягом доби (рух, лежання, стояння, прийом корму i т. д.). Чим більше тварин під наглядом, тим надійніше отримані результати. При спостереженні за декількома тваринами їх необхідно позначити фарбою (спеціальним маркером, синькою або фуксином), що наноситься на тулуб і дозволяє чітко відрізняти поросят між собою протягом доби.

В якості одиниці вимірювання 5-хвилинний інтервал протягом певного часу доби (не обов'язково повних, але з умовою спостереження за тваринами в період годування), тобто кожні 5 хв реєструється діяльність свиней. За допомогою скороченою записи поведінкових актів інформація заноситься до протоколу, потім обробляється і переноситься в підсумкову таблицю.

Нашою метою було розробити просту і доступну методику реєстрації рухової активності тварин. Для виконання поставленої мети ми використали класичні методичні підходи для визначення рухової активності тварин, тільки спростили систему реєстрації. Використовували тільки три критерії оцінки поведінки тварин: рухова активність; ссання свиноматки або прийом корму; перебування у статичному положенні. 3 метою зменшення кількості дослідників, усунення фактора присутності дослідника біля тварин (стрес) та унеможливлення технічних похибок в процесі заповнення протоколів досліджень ми використали відеореєстратор. Відеозаписи рухової активності тварин отримували за допомогою системи спостереження Danrou KCR-6324DR. Отримані результати зводяться в підсумковий протокол досліджень. Дана методика дослідження поведінки сільськогосподарських тварин має цілий ряд переваг, зокрема: моніторинг великої групи тварин одночасно; значно знижується трудоємність досліджень; можливість запису та подальшого аналізу звуків тварин; відеозаписи можуть слугувати для більш детального вивчення поведінкових реакцій тварин.

Таким чином, використовуючи подобові відеозаписи поведінки тварин ми отримуємо більш достовірні та глибокі данні їх рухової активності та етологічних особливостей.

\section{Список використаної літератури}

1. Менинг О. Поведение животных: Вводный курс. М.: Мир, 1982. 358 с.

2. Тинберген Н. Поведение животных. М.: Мир. 1969. 217 с.

3. Шилов И.А. Физиологическая экология животных.: Учебное пособие. М.: Высшая школа. 1985. 326 с.

4. Кононський О.I. Біохімія тварин: підручник для вузів. К.: Вища школа, 2006. 453 c.

5. Мазуркевич А.Й., Трокоз В.О., Карповський В.І.. Фізіологія сільськогосподарських тварин: підручник: видання друге, доповнене. к. нубіп україни, 2014. 456 с. 
6. http://earthpapers.net/formirovanie-pokazateley-povedeniya-sviney-vontogeneze-i-ispolzovanie-ih-dlya-otsenki-vosproizvoditelnyh-kachestv-vuslo\#ixzz31m6co65i.

7. http://www.rusagroug.ru/articles/1398.

8. Кудрин М.Р. Исследование поведенческих реакций ремонтных телок чёрно-пёстрой породы. Успехи современного естествознания. 2008. № 12. С. 3233.

9. Данчук О. В., Карповський В. І. Кортикальна регуляція інтенсивності пероксидного окиснення ліпідів та активності системи антиоксидантного захисту в організмі свиней [Текст]: монографія; Київ : НУБіП України, 2019. 216 с. ISBN 978617-7396-76-4.

10. Данчук В.В., Данчук О.В., Приступа Т.І., Добровольський В.А., Токарчук Т.С., Клюцук М.Р., Юрковський В.П., Карповський В.В., Карповський П.В. Методичні рекомендації «Визначення рухової активності у тварин». Типографія ПДАТУ. Кам.-Под. 2015. 39 с.

11. Губер Н.Б.. Этологическая реактивность бычков при использовании біостимулятора. Молодой ученый. 2013. № 11. С. 243-245.

12. Осадчая Ю.В. Этологические аспекты страусов в условиях фермы. Современные научные исследования и инновации. 2014. № 6. http://web.snauka.ru/issues/2014/06/35953

13. Щербатов В.И. Формироване еиерархической структуры группы животных в замкнутом пространстве. Научный журнал Куб. ГАУ. 2013. № 90 (06). http://ej.kubagro.ru/2013/06/pdf/47.pdf.

14. Миронова И.В., Валитова А.А., Савельева П.А. Этологическая реактивность телок бестужевской породы при введении в рацион природной добавки /. Http://catalog-statei.ru/view_article.php?Id=496

15. Приступа Т.І., Данчук В.В., Данчук О.В., Каплуненко В.Г.. Рухова активність поросят-сисунів за ведення сполук Феруму. Науковий вісник ветеринарної медицини. Біла Церква 2013. Вип. 12 (107). С. 60-63.

16. Данчук О. В. Пероксидне окиснення ліпідів та активність системи антиоксидантного захисту в організмі свиней з різними типами вищої нервової діяльності [Текст]: автореф. дис. ... д-ра вет. наук : 03.00.13 / Данчук Олексій Володимирович; Нац. ун-т біоресурсів і природокористування України. Київ, 2018. 46 c.

17. Приступа Т. І. Регуляція рухової активності, кровотворення та обміну ліпідів у поросят сполуками феруму [Текст]. автореф. дис. ... канд. вет. наук : 03.00.13; Нац. ун-т біоресурсів і природокористування України. Київ, 2016. 22 с.

\section{МЕТОДЫ ИЗУЧЕНИЯ ДВИГАТЕЛЬНОЙ АКТИВНОСТИ У ЖИВОТНЫХ}

В. Данчук, Т. Приступа, М. Клюцук, А. Данчук

В обзоре литературы приведены известные методы изучения двигательной активности у животных. Двигательная активность животных - это координированное сокращение скелетных мыши, сопровождающееся изменением положения тела в пространстве. Двигательная активность 
организма осуществляется с помощьюю системы движения. ЦНС отвечает на координациию движений тела, а сами движения выполняются мышцами с помощьью костей скелета и их соединений (суставов, а также неподвижных $и$ малоподвижных соединений костей). Все кости объединяются между собой различными видами соединительной ткани и образуют скелет - пассивную часть системы движения, а прикреплены к костям скелетныл мышць - ее активную часть. Есть довольно много методов и подходов определения двигательной активности животных. Целью данной работы было научно обосновать и обобщить сущуествующче методы определения двигательной активности сельскохозяйственных, домашних жсвотных и птицы.

Ключевые слова: двигательная активность, этология, животные.

\title{
METHODS OF STUDYING MOTOR ACTIVITY IN ANIMALS
}

\author{
V. Danchuk, T. Pristupa, M. Klyutsuk, O. Danchuk
}

The literature review presents known methods for studying motor activity in animals. Motor activity of animals is a coordinated contraction of skeletal muscles, which is accompanied by a change in body position in space. Motor activity of the body is carried out by the locomotor system. The CNS is responsible for coordinating the body's movements and the muscles through the skeletal bones and their joints (joints, as well as immobile and immobile joints of the bones) perform the movements themselves. All bones combine with different types of connective tissue to form the skeleton, the passive part of the locomotor system, and the skeletal muscles attached to the bones form the active part. There are many methods and approaches to determine the motor activity of animals. The purpose of this work was to scientifically substantiate and generalize the existing methods of determining the motor activity of farm and domestic animals and poultry.

Key words: motor activity, ethology, animals. 